\title{
Challenging airway in a paediatric patient impaled by a freezer pop stick
}

\author{
Edward J Park, ${ }^{1}$ Alexandra G Espinel, ${ }^{2}$ Rahul K Shah, ${ }^{2}$ Srijaya K Reddy ${ }^{3}$
}

${ }^{1}$ Department of

Anaesthesiology, Walter Reed National Military Medical Center, Bethesda, Maryland, USA

${ }^{2}$ Division of Otolaryngology, Children's National Health System, Washington, District of Columbia, USA

${ }^{3}$ Division of Anaesthesiology, Pain and Perioperative Medicine, Children's National Health System, Washington, District of Columbia, USA

\section{Correspondence to Dr Srijaya K Reddy, sreddy@cnmc.org}

Accepted 25 July 2017

\section{DESCRIPTION}

As experts of the human airway, it is our job as anaesthesiologists to control and secure the airway in the safest way possible for the patient. The perioperative anaesthetic plan always includes an airway component, ranging from bag-mask ventilation to endotracheal intubation. Routine surgical procedures may warrant a certain standardised airway strategy that may vary among institutions. However, there exist situations that are less common, in which standard airway practice is unclear. If the injury is suspected to be in a highly sensitive area and securing an airway may compromise or cause further injury, radiographic imaging may be warranted. ${ }^{1}$

Figure 1 depicts a paediatric patient impaled in the soft palate of the left oropharynx by a freezer pop stick that the patient had been previously enjoying and accidentally fell onto. (left of image). The CT scan portion of the figure is a contrast CT scan of the head and neck, in which the tract of the freezer pop stick is visualised. The most notable aspect is that the proximal (to the patient) end of the freezer pop stick lies only $2 \mathrm{~mm}$ anterior to the

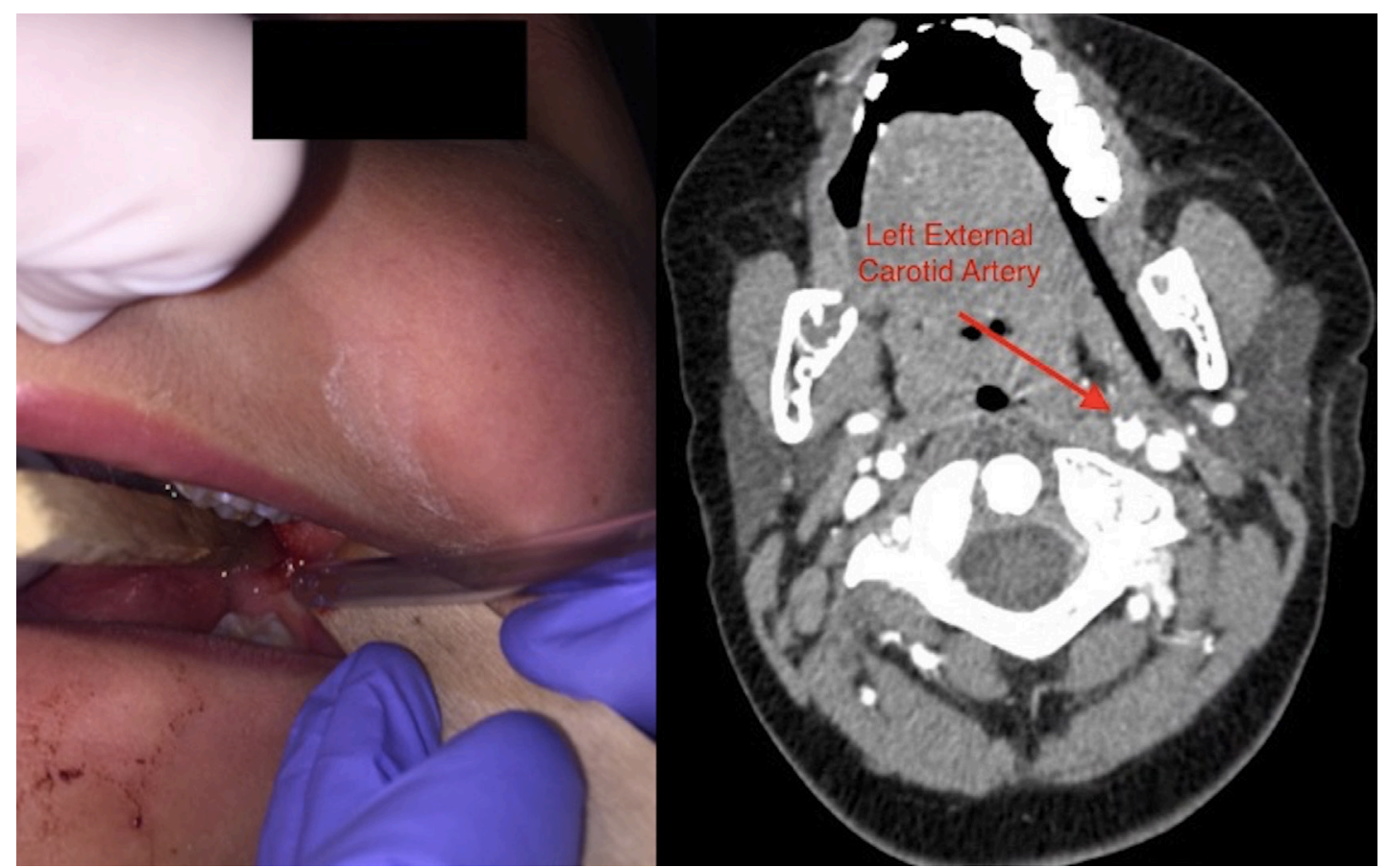

Figure 1 The left image shows the entry point of which the freezer pop stick impaled the patient's oropharynx. The right image is a contrast CT scan of the head showing the tract of the freezer pop stick in the soft tissue and its proximity to the left external carotid artery.

\section{Learning points}

- Prior to a general anaesthetic, consider use of advanced imaging modalities in specific trauma situations in order to best plan airway interventions.

- Time permitting, proper discussion with the surgical team prior to induction and intubation is warranted with secondary and tertiary options readily available if unable to gain airway control in patients where a foreign body may interfere. left external carotid artery. The main concern being that manipulation and securing of the airway could cause a shift of the foreign object with catastrophic results. $^{2}{ }^{3}$ Given this clinical context, the imaging study proved to help shape and plan our anaesthetic technique.

After extensive discussion and preparation with the ENT surgeon, the patient was induced via mask general anaesthesia and kept spontaneously ventilating. We were able to successfully secure the airway with an endotracheal tube with 
direct laryngoscopy using a video laryngoscope in the midline position of the airway (no sweeping of the tongue). This technique allowed us to simultaneously visualise the freezer pop stick and glottic opening, while avoiding any movement of the foreign body during intubation. The ENT surgeon was able to remove the freezer pop stick without any adverse events.

Contributors EJP was responsible for the initial written content as well as editing the manuscript and creating the image. AGE was responsible for reviewing and editing the manuscript. RKS was responsible for reviewing the manuscript and assisting with obtaining intraoperative image for the case. SKR was responsible for reviewing and editing the manuscript.

Competing interests None declared.
Patient consent Obtained.

Provenance and peer review Not commissioned; externally peer reviewed.

(C) BMJ Publishing Group Ltd (unless otherwise stated in the text of the article) 2017. All rights reserved. No commercial use is permitted unless otherwise expressly granted.

\section{REFERENCES}

1 Paterson NA. Management of an unusual pediatric difficult airway using ketamine as a sole agent. Paediatr Anaesth 2008;18:785-8.

2. Altan A, Damlar I, Kiliç S, et al. Unusual foreign bodies in the oral cavity: a Report of three cases. Sch J Dent Sci 2015;2:126-9.

3. Sidhu MK, Shaw DW, Roberts TS. Carotid artery injury and delayed cerebral infarction after minor pharyngeal trauma. AJR Am J Roentgenol 1996;167:1056.

Copyright 2017 BMJ Publishing Group. All rights reserved. For permission to reuse any of this content visit

http://group.bmj.com/group/rights-licensing/permissions.

BMJ Case Report Fellows may re-use this article for personal use and teaching without any further permission.

Become a Fellow of BMJ Case Reports today and you can:

- Submit as many cases as you like

- Enjoy fast sympathetic peer review and rapid publication of accepted articles

- Access all the published articles

Re-use any of the published material for personal use and teaching without further permission

For information on Institutional Fellowships contact consortiasales@bmjgroup.com

Visit casereports.bmj.com for more articles like this and to become a Fellow 